\title{
Ontolojik metin tahlili hakkında bazı tespitler'1
}

\section{Ulaș BİNGÖL²}

\begin{abstract}
APA: Bingöl, U. (2019). Ontolojik metin tahlili hakkında bazı tespitler. RumeliDE Dil ve Edebiyat
\end{abstract} Araştırmaları Dergisi, (14), 144-153. DOI: 10.29000/rumelide.541006

\section{$\ddot{\mathbf{O} z}$}

Ontolojik yöntem son yıllarda sıkça başvurulan metin tahlil tekniklerinden biridir. İsmail Tunalı'nın Sanat Ontolojisi isimli eserinde, Nikolai Hartmann ve Roman Ingarden’ın düşüncelerinden faydalanarak geliştirdiği ontolojik yöntem, edebiyat araştırmacıları tarafından özellikle şiir incelemelerinde kullanılmaktadır. Birçok araştırmacı, Tunalı’nın yöntemini bazı değişiklikler yaparak edebî metne uygulamaya çalışır. Ontolojik yönteme göre metin incelenirken genellikle iki konu göz ardı edilir: Birincisi edebî eserin var olmasını sağlayan yazar, ikincisi okuyucu veya alımlayıcı özne. Sanat faaliyeti; eser, sanatçı ve alımlayıcı öznenin içinde yer aldığı bir süreçtir. Ontolojik yöntem esere odaklanmasına rağmen sanatçı ve alımlayıcı öznenin varlığını yadsımaz. Ontolojik yöntem ile metin tahlili, şüphesiz bir metni çözümlemede araştırmacının disiplin içerisinde hareket etmesini sağlar. Araştırmacının metin dışı unsurları bir tarafa bırakarak metinin kendisine, başka bir deyişle metnin varlığına odaklanmasına olanak tanır. Tarafsız, bilimsel neticelerin alınmasında ve edebî metnin doğasının anlaşılmasında ontolojik yöntemin önemli katkıları olduğu yadsınamaz. Edebî eser, ontik bütünlüğünü aynı zamanda yazara ve okuyucunun varlığına borçludur. Bir eserin ontik bütünlük göstermesinde yazar ve alımlayıcı öznenin rolü, ancak sanat felsefesi ve estetik disiplini hakkında yeteri derecede bilgi sahibi olmakla bilinebilir. Nitekim İsmail Tunalı, ontolojik yöntemi metne uygulamadan önce sanat felsefesi ve ontolojinin sanat eserinin anlaşılmasındaki etkisine değinir. Bu çalışmanın amacı, ontolojik yöntem ile yapılan metin tahlillerinde öne çıkan bazı eksiklikleri ortaya koyup ontolojik yöntemde sanatçı ve alımlayıcı öznenin önemsenmesinin gereğini belirtmektir.

Anahtar kelimeler: Ontoloji, sanat ontolojisi, alımlayıcı özne.

\section{Some suggestions about ontological text analysis}

\begin{abstract}
In recent years, ontological method is one of the most used text analysis. It developed by İsmail Tunalı as take advantage of Nikolai Hartmann and Roman Ingarden thoughts in Art Ontology, particularly has been used poem analysis. Many researcher try to carry out it in literary text as adapt their work. It can be asserted that there are two important matters which ignored by researchers in ontological method. First matter is author who provides to exist literary work, second is reader or recipient subject. Art is an activity process that work, artist and recipient generate it. Although ontological method focuses on text, it does not deny author and recipient subject. To learn aesthetic value of one literary work, we must pay attention to them. A literary work obtains to its ontical integrity thanks to
\end{abstract}

Bu makale 12-14 Mayıs 2017 tarihleri arasında Erzurum'da gerçekleștirilen I. Uluslararası Türk Dili ve Edebiyatı Bilgi Şöleni Sempozyumunda sözlü olarak sunulan Ontolojik Metin Tahlili Hakkında Bazı Öneriler adlı bildirinin gözden geçirilmiş ve düzenlenmiş halidir.

2 Dr. Öğr. Üye. Siirt Üniversitesi, Fen Edebiyat Fakültesi, Türk Dili ve Edebiyatı Bölümü, (Siirt, Türkiye), ulasedebiyat@gmail.com, ORCID ID: 00oo-0003-3093-1036 [Makale kayıt tarihi: 12.02.2019-kabul tarihi: 07.03.2019; DOI: $10.29000 /$ rumelide.541006] 
author and recipient subject. Their role in ontical integrity of the text is known by somebody who knows sufficiently knowledge about art philosophy and aesthetic discipline. Thus, İsmail Tunalı mentions art philosophy and aesthetic discipline that it effects on text analysis before he uses ontological method in text. The aim of this paper is to put forth deficiency of ontological method and to show the importance of writer and recipient subject in ontological method.

Key words: Art ontology, ontology, recipient subject.

\section{Giriş}

Son yılların popüler metin inceleme yaklaşımlarından biri ontolojik yöntemdir. İsmail Tunalı'nın Sanat Ontolojisi adlı eserinde Nikolai Hartmann ve Roman Ingarden'ın düşüncelerinden faydalanarak geliştirdiği ontolojik yöntem, edebiyat araştırmacıları tarafından bazı değiş̧ikliklere uğratılarak özellikle şiir metinlerinde uygulanır. Şiir metinleri arasında ise divan şiiri metinleri analizine yönelen ontolojik yöntem çalışmalarının daha fazla olduğu göze çarpar. Araştırmacılar çoğu zaman Tunalı'nın geliştirdiği yöntem üzerinde bazı değişiklikler yaparak seçtikleri metinleri ontolojik yöntem yoluyla incelerler. Bazı araştırmacılar ise önceden yapılan çalışmalarda izlenen yolu aynen takip eder. Bu şekilde birbirinin benzeri olan birçok çalışma ortaya çıkar.

Ontolojik yöntem ile metin tahlili, şüphesiz bir metni çözümlemede araştırmacının disiplin içerisinde hareket etmesini sağlar. Araştırmacının metin dışı unsurları bir tarafa bırakarak metinin kendisine, başka bir deyişle metnin varlığına odaklanmasına olanak tanır. Tarafsız, bilimsel neticelerin alınmasında ve edebî metnin doğasının anlaşılmasında ontolojik yöntemin önemli katkıları olduğu yadsinamaz.

Ontolojik yönteme göre yapılan tahlillerin çoğu zaman birbirini taklit etmesi, araştırmacıların İsmail Tunalı'nın Sanat Ontolojisi dışında ontoloji disiplini hakkında başka bir eserden faydalanmaması, sanat eserinin estetik değerinin anlaşılmasında sanatçı ve okuyucunun geriye itilmesi ontolojik yöntemin şüpheyle karşılanmasına yol açar. XX. yüzylın başlarından itibaren sanat eserlerinin kendi içinde bir sistem olduğunu ve bu sistemin dış unsurlardan bağımsız bir şekilde incelenmesi gerektiğini iddia eden yapısalcılık ve biçimcilik gibi yaklaşımlar ontolojik yöntemin ortaya çıkmasını etkilemiştir. Yapısalcılık ve biçimcilik gibi yaklaşımlar, sanat eserini incelerken esere mekanik bir işleyiş olarak yaklaştıkları için yöntemleri de bir anlamda mekaniktir. Ontolojik yöntemin özünde, metnin mekanik bir yapı olarak ele almak yok iken yapılan çalışmalar çoğu zaman metne mekanik bir yapıymış gibi yaklaşır. Bir sanat eserine mekanik bir yapı olarak yaklaşmanın en büyük eksikliği sanatçı ve alımlayıcı özne faktörünün göz ardı edilmesidir. Öte yandan geleneksel şerhlerin çoğu zaman ontolojik yöntem ile aynı verileri sunmasına karşın araştırmacıların bu konuyu önemsememesi büyük bir eksikliktir. Ayrıca ontoloji hakkında yeterince malumata sahip olmadan metin analizine girişilmesi birçok çalışmanın kısır kalmasına yol açmaktadır. Ontolojik yöntemin sağlıklı neticeler vermesi için araştırmacının geleneksel şerh yönteminden faydalanması, ontoloji ve estetik hakkında yeterince bilgi sahibi olması, sanatçı ve okuyucu faktörlerini göz önünde tutması gerekir.

Tespitlere geçmeden önce ontolojik yöntemin ne olduğu ve hangi basamakları takip ederek metne yaklaştığını ele alacağız. 


\section{Ontolojik yöntem nedir?}

Türkçede varlık felsefesi olarak bilinen ontoloji, felsefenin en eski disiplinlerinden biridir. En kapsamlı anlamıyla ontoloji, "metafiziğin tek tek nesne ve olaylarla değil de, genel olarak varlık problemleriyle ilgili olan dalı; varlığı varlık olarak, varlık olma bakımından ele alan bilim[dir]" (Cevizci, 2013: 1192). Felsefenin ortaya çıktığı düşünülen Antik Yunan'dan günümüze ontoloji sürekli değişime uğrar. Varlığın kökenini, formunu ve özünü anlamaya çalışan düşünürler değişen dünya görüssleri çerçevesinde farklı yorumlarda bulunurlar. Thales'ten Herakleitos'a kadar birçok İlkçă̆ düşünürü varlığın kökeni sorusuna yönelir. Ortaçağ’da varlığın kökeni sorusu, din temelli düşüncenin baskısı nedeniyle geriye itilir, modern zamanlarda epistemoloji varlığı bir bilgi nesnesi olarak ele aldığından ontoloji eski önemini yitirir. XIX. yüzyılın sonlarında gelişen Egzistansiyalist felsefe ontolojinin epistemolojinin etkisinden kurtulması gerektiğini savunur. Descartes’in cogito temelli varlık anlayışını eleştiren Egzistansiyalistler, varlığı varlıkta anlamlandırmaya çalışırlar. Martin Heidegger de "artık cogito merkezli felsefeler yerini varlık merkezli felsefelere bırakmalıdır” (Çüçen, 2012: 18) derken yeni ontolojik yaklaşımın özelliklerini belirler. İsmail Tunalı ontolojik yöntemi geliştirirken faydalandığı Nikolai Hartmann ve Roman Ingarden bu yeni ontolojik yaklaşıma bağlıdırlar.

Nikolai Hartmann öncelikle ontolojinin epistemolojinin etkisinden kurtulması gerektiğini düşünür. Hartmann'a göre "bilgi daima aşkındır, onun için önemli olan nesnenin nasıl düşünüldüğü değil, nesnenin nasıl olduğudur; tüm bilgi donanımı da nesnenin kavranması içindir" (2010: 8). XIX. yüzyıl sonlarında ve XX. yüzyılın başlarında sanat eserlerinin giderek sosyoloji ve psikolojinin gölgesinde incelenmesi sanat eserinin bir var olan olarak değerinin ikinci plana atılmasına neden olmuştur. İşte tam da bu noktada Nikolai Hartmann'in yeni ontolojisi sanat eserini bir var olan olarak ele almayı hedefler. Bu ontolojik yaklaşım kategoriler üzerine kurulmuştur. Hartmann'a göre sanat eseri bir objektivasyondur, objektivasyon ise var olmayan bir şeyin ortaya konmasıdır. Objektivasyonda bir eylem ve bir yaratma söz konusudur (Bingöl-Ciğa, 2014: 285). Sanat eserini reel ön yapı ve irreel arka yapı olmak üzere ikiye ayıran Hartmann, arka yapının ön yapıya bağlı olmasına karşın tinsel bir yönünün olduğunu belirtir.

Roman Ingarden, sanat eserini varoluş ve fenomenoloji çerçevesinde inceleyen ve alımlama estetiği kuramını geliştiren kişilerden biridir. Sanat eserinde aşkınsallığı reddeden Ingarden, bir edebî eserin dört bölümde inceler: "1. Dil sesleri düzeyi, 2. Anlam ile ilgili olan anlam birimleri, 3. Eserde dil yolu ile görünür kılınan birbirine örülü görüşler, yönlendirmeler, 4. Eserde varlıkların görüş alanına çıkış biçimlerinin, varlık temellendirmelerinin, dünya düzeyine paralel yer alışı” (Ergiydiren, 2007: 50). Ingarden, edebî eserlerin maddi kısımlarının seslerden, kelimelerden oluştuğunu ve maddi kısmın anlam kısmını yönlendirdiğinden söz eder.

İsmail Tunalı, Roman Ingarden'in edebî eseri ontik tabaklara ayırmasından hareketle Yahya Kemal'in Sessiz Gemi ve Cahit Sitkı'nın Gün Eksilmesin Penceremden şiirlerini sırasıyla ses, anlam, obje ve alın yazısı tabakalarına göre inceler. Ses tabakası olan maddi yapıda edebî eserin ritim, ölçü, ses gibi unsurlarını ele alır. Anlam tabakasında; tek tek kelimelerin hangi anlamda kullanıldığına, obje tabakasında; metaforları, analojileri, imgeleri nasıl işlendiğine, alın yazısı tabakasında; edebî metinde verilen genel mesaja değinir (Tunalı, 2011: 114-115). Tunalı'ya göre ontolojik yöntem araştırmacılara bir metodoloji sunduğu için kolaylıkla sanat eserlerine uygulanabilir. Öte yandan sanat eserinin bütünlüğünü bozmamaya gayret gösteren ontolojik yöntem, incelemenin eserin dışına taşmamasına gayret eder. 
İsmail Tunalı'nın geliştirdiği yöntem, birçok araştırmacı tarafından uygulanmıştır. Özellikle Yavuz Bayram'ın Divan Şiiri Metinlerinin Ontolojik Tahlili Üzerine adlı çalışmasında geliştirdiği tablo, birçok araştırmacı tarafından kullanılmıştır. Bayram da edebî eseri Tunalı gibi arka yapı ve ön yapı olmak üzere iki temel tabakaya ayırarak inceler. Ön yapıda sesler, harfler, nazım şekli, redif ve kafiye gibi unsurları ele alır. Arka yapıyı ise dörde ayırır: Anlamsal tabaka, obje tabakası, karakter tabakası, kader tabakası. Anlamsal tabakada; kelime ve cümle semantiğini, obje tabasında; anlamı üzerinde ağırlıklı olarak taşıyan kelimeleri, karakter tabakasında; şairin psikolojini ve yetiştiği ortamı, kader tabakasında; tespitlerin bütün insanlık için genelleştirilmesini inceler (Bayram, 2008: 6).

\section{Ontoloji ve ontolojik yöntem}

Sanatın mahiyeti ile ilgi Antik Yunandan günümüze insanlar kafa yormuşlardır. Sanat kimi zaman bir oyun, kimi zaman insan eğitimi için bir araç kimi zaman da büyü olarak adlandırılmıştır. Sanatla ilgili bütün görüşlerde değişmeyen tek gerçek "sanatın bir insan etkinliği” olduğudur. Bir süreç olarak sanat, daima somut bir eserin varlığını içinde barındırır; o varlık sanat eseridir. Bir tablo, bir müzik parçası ve bir roman "var"dır. Var olan bir şey ise ontolojinin (varlık felsefesi) araştırma alanına girer. Varlık felsefesinde, sanat eserlerinin varlı̆̆ını inceleyen dal ise sanat ontolojisidir. Sanat ontolojisini Tunalı, "sanat eseri dediğimiz var-olanları var-oluşları yönünden inceleyen bir felsefedir" (2011: 5) diyerek tanımlar. Bu tanımdan yola çıkılırsa sanat eserinin her şeyden bağımsız olarak varlığı ve varoluşu merkeze alınarak ele alınması gerekir. Nitekim Tunalı da ontolojik tahlil denemelerinde eserin bu iki yönünü açıllamayı ihmal etmez.

Ontolojik inceleme denemelerinde, sanat eserinin varlığı üzerinde ziyadesiyle durulmuştur. Fakat bir varoluş olarak sanat eserleri hakkında başta Heidegger olmak üzere birçok düşünür açıklamalarda bulunmasına rağmen yapılan ontolojik incelemelerde bu açıklamaların dikkate alınmadığı görülür. Sanat eserinin bir varoluş olduğu görüşünden yola çıkarak ontolojik tahlile yeni bir bakış kazandırılmalıdır. Onun için sanat eserinin varoluşunun ne demek olduğu ve bu varoluşun unsurlarına eğileceğiz.

Heidegger sanat eserinin varoluşunu anlamak için sanat eserinin kökenine inilmesi gerektiğini vurgular. Ona göre "bir şeyin kökeni onun varlığının kaynağıdır. Sanat eserinin kökeni sorusu, onun özünün kökeni sorusunu da içerir” (2011:9). Eserin kökenini başka bir deyişle söylersek ilk nedenini anlarsak sanat eserini de açımlayabiliriz. Heidegger, sanat eserinin sanatçının faaliyeti olduğunu söyledikten sonra sanatçının eser sayesinde ortaya çıktığını belirtir. O halde eserin kökeni sanatçı olduğu gibi sanatçının varoluşu da eserin kendisidir, çünkü eser kişiyi sanatçı olarak ortaya çıkarır. Heidegger’in eserin kökeni olarak sanatçıyı işaret etmesi görüşüne Aristoteles’in düşüncelerinde de rastllyoruz. Aristoteles'e göre "bir sanat eserinin oluşumunda form, sanatçının ruhundadır" (Çüçen, 2011: 145). Hegel de sanatın tinden doğduğunu ve onunla var edildiğinden söz ederek sanat eserinin varlığının sanatçıly bitişik olduğunu söyler (1994:2). Fakat Heidegger, sanatçının varoluşunun da sanat eserinde ortaya çıktığını, bu yüzden sanat eseri ile sanatçı arasındaki ilişkinin sürekli devam ettiğini ileri sürer ve Aristoteles'ten farklı bir tavır takınır. Heidegger’in düşüncelerinden yola çıkılırsa ontolojik bir incelemede öncelikli olarak sanatçının varlığına odaklanmalıdır. Fakat sanatçının varoluşunun sanat eserinde kendisini açımladığı gerçeğini de göz önünde bulundurmalıdır. 


\section{Sanatçı ve eser}

Birçok modern tahlil yöntemi gibi ontolojik yöntem de metne yaklaşırken sanatçının varlı̆̆ına gözünü kapar. Rus Biçimcilerinden itibaren edebî metinlerin bir iç işleyişinin olduğu ve bu iç işleyişin dil mekanizması sayesinde ortaya çıktığı görüşü ortaya atılmıştır. Rus Biçimcilerine göre araştırmacıların odaklanması gereken unsur eserde yazınsallı̆̆ sağlayan bu iç işleyiştir. Yapısalcılık ve göstergebilim de sanatçının varlığına tamamen gözünü kapayarak metnin kendisine yoğunlaşır. Ontolojik yöntemde sanatçının varlığının yapısalcılık ve göstergebilimde olduğu kadar göz ardı edilmemesine karşın yeterince dikkate alınmaz. Esas itibariyle İsmail Tunal, sanatçının varlığına daima değinme gereği duyar. Buna rağmen ontolojik yöntemin uygulandığı birçok çalışmada seslerin, harflerin, kelimelerin, edebî sanatların tablo halinde sunma uğraşına girildiği görülür. Yine birçok çalışmada sanatçının kişiliği ile edebî eserin ontik bütünlüğü arasında bağlantı kurmaya önem verilmez.

Sanat eserinin bir varlık olarak dış dünyada bulunduğu doğrudur ve her varlık gibi ontoloji çerçevesinde değerlendirilebilir. Fakat ontoloji aynı zamanda varlıkların ortaya çımasında dış faktörlere ve ilk nedenlere değinir. Varlığı salt kendi içerisinde değerlendiren Egzistansiyalist görüşler bile varoluşu incelerken farklı varlıklar arasındaki bağa dikkat çekerler. Sanat denilen faaliyet bir süreçtir ve bu sürecin ilk başladığı yer sanatçının kendisidir. Sanatçı olmadan eser olamayacağına göre eserin ontik yapısı üzerinde sanatçının izleri belirir. Sanatçı eserin aslında ilk nedenidir ve Aristoteles’in söylediği üzere bir şeyin ilk nedeni anlaşılırsa o şeyle ilgili her şey anlaşlır. Hem eserin kökeni o eserin varoluşuna işaret ediyorsa incelemeye kökenden başlanması daha sağlıkı olur. Sanat eserinin kökeni ise yaratıcı deha yani sanatçıdır. Bundan ötürü ontolojik yöntemde sanatçı ile eser arasındaki ilişkiye dikkat çekmenin eserin ontik yapısının daha iyi anlaşılmasına yardımcı olacağı düşünülebilir.

Edebiyat eleştirisinin bilimin etkisinde kalması, araştırmacıların metin tahlil ederken bilimsel davranma endişesi ile hareket etmesine yol açar. Modern edebiyat eleştirisi kuramlarının genellikle yazarın varlığına odaklanmayı bilim dışı görmesi, edebî eserlerin doğada bulunan herhangi bir nesne gibi incelenmesine neden olmuştur. Bilim dışarıdaki bir nesneyi incelerken onu gözlemler, analiz eder. Bilim adamı için elde ettiği sonuçların doğruluğu hayati önem taşır. Edebî eser incelenirken bilimsel anlayış ile hareket edilmesinin en büyük güçlüğü edebî eserin sıradan bir nesne olmamasıdır. Eleştirmenin eser hakkında yargılarının tam olarak doğru olması diye bir şey söz konusu olamaz. Bir tahlil yöntemi bilimin etkisinde olsa bile esere yaklaşırken estetiğin ilkelerine göre hareket etmek zorundadır. Çünkü her sanat yapıtı gibi edebî yapıtlarda da güzelin kuralları işler. Eserde güzelliğin kaynağı ise eserin ilk nedeni, yani eseri ortaya koyan sanatçıdır.

Çağımızda yazarın bütünüyle öldüğünü iddia eden eleştiri yaklaşımları popüler hale gelmiştir. $\mathrm{Bu}$ eleştirilerin aksine sanat felsefesinin önde gelen isimleri, sanatçının varlığına daima önem verirler ve eserde sanatçıdan bir parçanın var olduğuna dikkat çekerler. Kant, sanatçının imgelem dünyasının önemine vurgu yapar. Ona göre güzeli eserde işleyen yetenek dehadır ve sanatın kurallarını dehanın kendisi belirler. Dahi kişi sanat eserini ortaya koymaya yatkındır (Kant, 2011: 176). Eserde ortaya konan güzellik ancak dehanın bir yansımasıdır. Kant estetiğinde, sanatçı özel bir varlıktır ve onun icra ettiği sanat, imgeleminin, ruhunun, zekâsının bir uyumu olarak görünür. Hegel de sanatçının özel bir varlık olduğu görüşünü paylaşır. Ona göre sanatçının "düşgücünün üretici etkinliği, deha, yetenek vb. diye adlandırılan şeydir; sanatçı bu etkinlik sayesinde, kendinde mutlak olarak akılsal olan şeyi alır ve ona dışsal bir biçim vermek suretiyle, onu kendi öz yaratımı olarak işleyip ortaya koyar” (Hegel, 1994: 282). Alman düşünür, sanat eserini sanatçının tinselliğinin dışa vurulduğu yer olarak değerlendirir. Robin George Collingwood da sanat eserinin bütünüyle sanatçının zihnindeki bir düşünce veya bir duygu 
olduğunu söyleyerek sanatçının varlığını öne çıkarır. Onun düşüncesine göre sanat eserinde sanatçının zihnindeki duygu veya fikrin sadece bir kısmı ortaya çıkar, diğer kısım sanatçının zihninde bulunmaya devam eder. $\mathrm{O}$ halde sanatın bir parçası sanatçıda bulunur.

Sanat eserinin anlaşılmasında sanatçının önemine vurgu yapan Kant ve Hegel dışında birçok düşünür vardır. Öteden beri birçok sanat felsefecisi, sanatçının özel bir varlık olduğunu ve sanat eserinin sanatçının imgelem gücünün bir ürünü olduğunu belirtir. Bir edebiyatçı, bir heykeltıraş veya bir ressam eserini ortaya koymadan önce zihninde onu tasarlar. Dış dünyadan aldığı malzemeyi imgelem gücüne göre bir biçime soktuktan sonra bir nesne üzerinde yeniden canlandırır. Tasarlanan malzeme daima bir değişime uğrar. Bir araştırmacı, değişime uğrayan bu malzemeyi incelerken tasarımcıyı göz ardı etmemesi beklenir. Sanat eserinin her parçasında sanatçının imgelem dünyasının etkileri vardır. Eserin ontik yapısı ele alınırken muhakkak sanatçının imgelem dünyasının etkisine değinilmelidir. Çünkü malzemeyi esere dönüştüren imgelem dünyasıdır.

Bir sanat eserinin çözümlemesinde belirleyici olan malzemedir. Edebî eserlerin malzemesinin dil olması, çözümlemenin dile yoğunlaşmasını zorunlu kılar. Ontolojik yöntem dilsel malzemeye yoğunlaşması açısından önemlidir. Fakat edebiyat eserinde işlenen dilin günlük dilden farklı olduğu, yazarın dili kullanma biçiminin edebî eserin yapısını belirlediği göz ardı edilmemelidir. Edebiyatçı da genelin konuştuğu dilden aldığı malzemeleri kullanır, ama bu malzemeleri kullanırken kendi imgelem dünyasının süzgecinden geçirir. Edebiyatçının kullandığı sözcüklerin anlamsal bağlamı çoğu zaman değişime uğrar. Siradan birisinin gece sözcüğünden anladığı ile bir edebiyatçının gece sözcü̆üunden anladığı şey farklı olabilir. Edebiyatçı geceyi eserinde değişik çağırışımlar uyandıracak şekilde kullanabilir ya da edebiyatçının geçmişte yaşadıkları geceyi değişik bir biçimde anlamasını ve eserinde anladığı şekli ile kullanmasını etkileyebilir. Öte yandan farklı edebiyatçılar bir sözcüğü değissik anlamları çağrıştıracak biçimde kullanabilir. Mesela Cahit Sıtkı Tarancı ile Ahmet Haşim’in gece sözcügüunü kullanma şekillerini karşılaştıralım:

\author{
Bütün güzelliğiyle gece çırılçıplaktı; \\ Yıldızlarıyla sema gül dolu bir kucaktı, \\ Dünya saadet tüten neşeli bir ocaktı. \\ Bütün güzelliği ile gece çırılçıplaktı \\ Ve bir ses; “-Bülbül böyle bir gece öter!” dedi (Tarancı, 2005: 37)
}

Cahit Sıtkı'nın Ölümden Beter şiirinden alınan bu kısımda gece güzelliği ile öne çıkan bir unsurdur. Burada geceyi sadece sözcük anlamı ile ele almak yanlıştır. Çünkü şairin zihninde gece, tabiatın diğer unsurları ile birlikte güzel bir bütünlük oluşturmaktadır. Fakat şiirin sonunda ölüm hakikati bu güzel bütünlüğü bozar. Cahit Sıtkı Tarancı'nın edebî şahsiyeti, karakteri, başından geçenler bilinmeden gecenin bu şiirdeki işlevi tam olarak bilinemez. Gece de diğer tabiat unsurları gibi şairi hayata bağlar, ona neşe verir. Ahmet Haşim’in $O$ şiirinde ise gece şöyle geçer:
Nehrin gece, rü'yâ ve serâirle boğulmuş
Ufkunda tahassürler okur gam-zede bir kuş.
Bir giryeli ses -belki kadın, belki de erkek-
Söyler gecenin şi’rine bir aşk, bir ahenk... (Haşim, 2007: 45)

Bilindiği üzere Ahmet Haşim, akşam ve gece imgelerini şiirlerinde sıkça kullanır. Haşim’in gece ve akşam imgelerini sıkça hangi bağlamlarda kullandığı sadece metinlerinin ontolojik tahlili yapılarak 
anlaşılabilir mi? Ontolojik yöntem eseri incelerken dış unsurları göz ardı ettiği için Haşim'de gece ve akşamın anlamını tam olarak anlamak zordur. Haşim'in hasta olan annesi ancak geceleri dışarı çıkabiliyordu. Haşim annesinin bu durumundan etkilendiğinden $O$ şiirinde annesini anlatmaktadır. Gece imgesi de şairde, annesinin durumuna göre biçimlenmiştir. Cahit Sitkı'da gece mutluluğu çağrıştırırken Haşim'de üzüntü ve keder ile ilişkilidir. Görüldüğü üzere eseri yazarından bă̆ımsız değerlendirmek ve sözcükleri kendi başlarına anlamlandırmaya çalışmak her zaman doğru bir yöntem değildir. Edebiyatçının yaşamı, karakteri, beklentileri ve korkuları sözcüklere farklı anlamlar yüklemesine yol açabilir. Ontolojik yöntem ile metin tahlil eden araştırmacıların edebî eserin doğasını daha sağlıklı inceleyebilmeleri için sanatçının varlığını göz önünde bulundurmalarında fayda vardır. Nitekim sanat ontolojisinde de sanatçının eserin ontik yapısı üzerindeki etkisi yadsınmamıştır.

\section{Okuyucu ve eserin ontolojisi}

Geleneksel yaklaşımlardan modern tahlil yöntemlerine doğru birçok değişim yaşanmıştır. Bu değişimlerden en büyüğü, şüphesiz edebî eserin çözümlenmesinde okuyucu faktörünün öne çıkmasıdır. 1960'larda Almanya ve Fransa'da okuyucunun edebî eserin anlaşılmasında belirleyici olduğu görüşü yayllır. Hans Robert Jauss, Roman Ingarden, Rainer Warning, Wolfgang Iser gibi isimlerin temsil ettiği ve adına alımlama estetiği denilen yeni yaklaşım edebî eserin estetik değerinin okuyucunun beklentilerinin belirlediğini ileri sürer.

Ontolojik metodu edebî eserlere uygulayan ilk kişi olan Roman Ingarden, aynı zamanda alımlama estetiğinin önde gelen temsilcilerindendir. Roman Ingarden, edebî eserde her şeyin belirlenemeyeceğini, metinde bazı belirsizliklerin başka bir ifadeyle anlam boşluklarının mevcut olduğunu söyler. Okuyucu var olan anlam boşluklarını kendine göre doldurarak metni alımlar. Ingarden, söz konusu durumu somutlaştırma olarak ifade eder. Okuyucu anlam boşluklarını doldururken aynı zamanda edebî eserden alımladığı anlamları başka alanlarla bağdaştırarak yeni anlam evreleri kurar. Ingarden bu durumu ise yeniden kurma olarak isimlendirir. Wolfgan Iser de Ingarden'e benzer bir şekilde anlamayı okuyucu ile metnin ortak üretimi sürecinin sonucu olarak oluştuğunu savunur. Ingarden'ın alımlamayı belirsizliklerin belirlenmesi olarak tanımlamasına karşın Iser, alımlamıyı boşlukların doldurması olarak değerlendirir. Iser'e göre "yapıt metnin okurun bilincinde oluşmuş olma halidir. Edebiyat yapıtlarında, okur ve metin arasında oluşan etkileşim sırasında metnin anlamı oluşur ve bu etkileşimin nasıl olacağının sadece temel koşulları metnin yapısı belirler (Iser, 1990: 39 aktaran Toprak, 2003: 141). Iser'e göre anlama sürecini yöneten okuyucunun beklentileridir. Okurun beklentileri, edebî metinde olmayan ama okuma sırasında meydana gelen kodları da çözer.

Bir sanat eserin varoluşunun önemli bir yanını oluşturan estetik değer, alımlayıcı özne olmadan ortaya çıkarılamaz. Edebî eser söz konusu olduğunda alımlayıcı özne okurdur. Okurun da sanat sürecine dahil olduğu, eserde yeni anlam boyutları yakaladığı özellikle alımlama estetiği ile gündeme getirilmiştir. Wolfgang Iser, edebî bir eserde yazarın kurguladığı anlamlar ne olursa olsun, her okurun anlamları seçerek farklı vurgular yaparak alımladıklarını söyler (Ergiydiren, 2007: 66). Yani bir eser, onu alımlayan her kişiye yeni anlam katmanları sunarak kendisini yeniden var eder. Bu şekilde sanat eserinin varoluşu kendisini zaman içerisinde tekrar tekrar ortaya koyar. Eğer araştırmacı sanat eserinin varlı̆̆ını ve varoluşunu inceleyecekse alımlayan öznelerin sanat eserini kendilerine göre anlamlandırmalarını göz önünde bulundurması gerekir.

Ingarden, edebî metni ontik bir bütün olarak ele alırken okuyucunun önemine dikkat çeker. Ona göre okur edebî eserdeki varoluşsal ilişkileri örerek bir iskelet oluşturur. Bu iskeleti daha sonra beklentilerine 
ve ön bilgililerine göre dönüştürür. Edebî metnin anlamı böylece okuyucunun beklentilerine ve ön bilgilerine göre oluşur. Başka bir ifade ile metnin ontik bütünlüğü, okuyucunun anlamlandırması sayesinde meydana gelir. Eğitim ve kültür düzeyi, ideolojik tercihler, kişilik yapısı, yaş gibi faktörler okuyucunun beklentisini belirler. Bu gibi değişken faktörlerden dolayı her okuyucunun beklentisi farklıdır. Dolaysıyla her okuyucu kendine göre metni anlamlandırır. Edebî metnin anlamı okuyucudan okuyucuya değişiyorsa o zaman metnin ontik yapısı da değişkenlik gösterir. Çünkü anlam bir metnin ontik bütünlüğünün temel unsurlarındandır. Araştırmacıların edebî bir metni tahlil ederken okuyucunun rolüne dikkat etmeleri, metnin ontik bütünlügünün anlaşılmasında önemlidir.

\section{Klasik şerh ve ontolojik yöntem}

Modern tahlil yöntemlerine olan ilginin aksine klasik şerh yöntemine olan merak günden güne azalmaktadır. Araştırmacıların modern tahlil yöntemlerini cazip görmeleri, divan edebiyatı kültüründen giderek uzaklaşılması, geleneksel bakışlara yönelik bir ön yargının olması gibi nedenlerden ötürü klasik şerh yöntemlerine rağbet edilmemektedir. Oysa klasik şerh yöntemlerinde metne yaklaşım tarzının birçok açıdan ontolojik yöntemi çağrıştığı görülür. Mesela Cem Dilçin’in Fuzulî’nin bir gazelini şerh ettiği bir bölümünü ele alalım:

Dost bî-pervâ felek bî-rahm devrân bî-sükûn

Derd çok hem-derd yok düşmen kavî tâli’ zebun

"Dost pervasızdır, aşıka kayıtsız kalmakta, ilgisiz davranmaktadır. Felek merhametsizdir, acıması yoktur. Dünyada sükûn kalmamıştır, sürekli olarak durmadan dönmektedir. Aşıkın derdi pek çoktur, buna karşılık bu derde ortak olacak, bu derdi paylaşacak bir kimse de yoktur. Düşman güçlü, zorlu ve dayanıklıdır. Talih ise zayıf, güçsüz ve yenik düşmüştür." Buraya kadar Dilçin, beyitin düz anlamını açıklar. Bu kısım ontolojik metin tahlilinin anlam tabakasına eş değer görülebilir. Dilçin daha sonra beyitte anlam taşıyıcı kelimelere yoğunlaşır: "Dost kayıtsız ise, hiçbir şeye bağlı değilse vücûd-ı mutlak'tır yani Tanrı'dır. Kayıtsız, 'lâ-kayd' da demek olduğuna göre, aşıka 'ilgisiz' anlamına gelir." Dilçin, daha sonra felek ve devrân sözcüklerinin de anlamlarını inceler. Bu kısım ontolojik metin tahlilinde analojilerin, metaforların ele alındığı obje tabakası ile eş değer görülebilir. Dilçin, beyitti şerh ederken şairi de unutmaz: "Fuzulî aşk derdinin çok olduğunu, bu kadar çok derdi tek başına yalnız kendisine yüklendiğini, kendisinden başka bu derdi çeken bir kimse olmadığını, bu konuda tek olduğunu anlatmaktadır. Ona göre en büyük aşık kendisidir.” Görüldüğü gibi Dilçin, beyitte Fuzulî’nin karakterinin izlerini ele alır. Bu kısım ontolojik yöntemin karakter tabakasına benzetilebilir. Dilçin’in beyit hakkındaki şu açıklamaları da dikkat çekicidir: "İnsanın düşmanı nefstir. Nefs, insanı dünya işlerine ve kötü şeylere yönelten güçlü bir düşmandır. İnsanın talihi de, bu düşmana karşı koyacak ölçüde güçlü değildir ve nefs düşmanına yenik düşmüştür.” Dilçin’in buradaki çıarımları ontolojik yöntemin kader tabakası ile benzerdir. Dilçin'in şu açıklamalarını da ses tabakası ile ilişkilendirmek mümkündür: "Beyitte, dost/düşmen, çok/yok ve kavî/zebun arasında tezat yapılmıştır. Çok/yok arasında baştaki bir ünsüzü değili cinas olan cinas-ı lâhık sanatı vardır. Ayrıca felek devran ve tali’ sözleri arasında tenasüp sanatı vardır."

Cem Dilçin’in Fuzulî’nin yukarıdaki beyitinin şerihini bölümlere ayırıp her bölümün başına ontolojik yönteme uygun başlık konulursa ontoloji yöntem ile yapılmış bir tahlil çalışması ortaya çıkar. Cem Dilçin’in ontolojik metin ile beyiti tahlil etme niyetinde olduğu düşünülemez. Burada araştırmacıların 
ontolojik yöntemi kullanırken geleneksel şerh yöntemlerinden rahatlıkla yararlanabileceği görülmektedir. Bizim yeni ve modern dediğimiz yöntemlerin bir kısmının uzun zaman önce Türk edebiyatında ismi konulmadan var olduğu düşünülebilir. Araştırmacıların yeni yöntemlerden yararlanmaları önemlidir fakat kendi edebiyatında var olan anlayışları görmezden gelmesi büyük bir hatadır. Cem Dilçin, adı anılan makalede Fuzulî’nin gazelini ilk önce geleneksel açıdan şerh eder, daha sonra modern yaklaşımlardan yapısalcıllğa göre gazeli yorumlar. Modern teknik ile geleneksel şerh yönteminin bir arada olması açısından çalışmanın araştırmacılara yol gösterici niteliği vardır. Özellikle divan şiiri metinlerini ontolojik metin ile inceleyen araştırmacıların geleneksel şerhten faydalanmaları, metni anlamalarına ve yorumlamalarına yardımcı olacaktır. ${ }^{4}$

\section{Sonuç}

Ontolojik inceleme temelde metin merkezli bir yöntemdir. Bu yöntem sayesinde sanat eserinin varlığı sürekli göz önünde bulundurulur ve sanatın dışına çıkılmadan tespitler bulunulur. İlk bakışta sanat eserini merkeze almasından dolayı objektif ve sağlıkı bir inceleme yöntemi olduğu düşünülen ontolojik yöntemin bazı problemleri barındırdığı görülür. Birinci problem, ontolojik yöntemde eseri vücuda getiren ve eserin ilk nedeni olan yaratıcı deha incelemeden dışlanılır. İkinci problem, sanat denilen sürece dâhil olan estetik alımlayıcıların eserdeki yeni katmanların ortaya çıkmasındaki fonksiyonundan bahsedilmez. Sanat eseri, her ne kadar dış dünyada var olan bir gerçek olsa da o gerçeğin başlangıcı sanatçıdır. Ayrıca sanat eserleri tek başlarına var olsalar da, bir estetik alımlayıcı (okuyucu, dinleyici, seyirci) olmadan barındırdıkları anlam katmanlarını duyuramazlar.

Sanat denilen etkinliğinin bir süreç olduğu söylenebilir. Bu sürecin unsurları sanatçı, eser ve alımlayıcı süjedir. Sanat yaratıcı bir dehadan başlar, sanat eserinde somutlaşır, alımlayıcı öznelerin eserle etkileşime girdiği her anda kendini yeniden ortaya koyar. Ontolojik yöntemin, eserin varlığına dâhil olan sanatçı ve alımlayıcı süjeyi dışladığından birtakım sakıncalı yanlarının olduğu ileri sürülebilir. Ontolojik yöntemde; sanatçı, alımlayıcı süje ve eserin kendisini birlikte göz önünde bulunduran bir yaklaşımın esas alınması, eserin ontik bütünlüğünün ortaya çıarılmasında daha sağlıklı bulgular elde edilmesine katkı sağlar.

Modern teknikler, divan şiirlerinin anlaşılmasında şüphesiz araştırmacılara yeni bakışlar kazandırır. Metnin farklı yönlerden ele alınması, metnin estetik değerinin anlaşılmasında yapıcı rol oynar. Fakat sürekli tekrar edilmiş bir tekniğin olduğu gibi başka metinlere uygulamanın edebî eserin doğasından kaynaklanan sakıncaları vardır. Her şeyden önce ontolojiye göre her varlık gibi edebî eserler de eşsizdir ve kendi içinde değerlendirilmesi gerekir. Bir edebî metin belli açlardan diğer eserlere benzeyebilir fakat tek başına vardır. Onun estetik değeri kendisinden ve onunla temasa geçen alımlayıcı özneden kaynaklanır. Aynı yöntemin farklı metinlere uygulanması, araştırmacıyı sürekli aynı sonuçlara götürebilir. Oysa bir edebî eserin estetik değeri, diğer eserlerle olan benzerliğinde değil, eşsizliğinde yatar.

İsmâ̂ll Rusûhî-yi Ankaravî’nin XVII. yüzyılda yazdı̆̆ı mesnevi şerhi, metin inceleme noktasında araştırmacılara ciddi katkllar sağlar niteliktedir. Günümüz Türkçesine uzak olan bu ve benzeri şerhlerin üzerinde durulmasının Türk edebiyatında eleştiri kültürünün zenginleşmesine yardımcı olacaktır. Bk. Tanyldız, Ahmet (2010). İsmâ̂ll Rusûhî-yi Ankaravî Şerh-i Mesnevî (Mecmû'atu'l-Letâyif ve Matmûratu'l-Ma'ârif) (I. Cilt) (İnceleme-Metin-Sözlük). Erciyes Üniversitesi Sosyal Bilimler Enstitüsü, Basılmamış Doktora Tezi, Kayseri. 


\section{Kaynakça}

Bayram, Yavuz (2008). Divan Şïri Metinlerinin Ontolojik Tahlili. Prof. Dr. Abdülkadir Karahan Anısına Uluslararası Divan Edebiyatı Sempozyumu, 27-28 Mayıs 2008, Beykoz Belediyesi, İstanbul 2008, s.167-182.

Bingöl, Ulaş-Ciğa, Özkan (2014). Ontolojik Metin Tahlili Ve Şeyh Gâlib’in Bir Gazelinin Ontolojik Tahlili. Turkish Studies - International Periodical For The Languages, Literature and History of Turkish or Turkic Volume 9/9 Summer 2014, p. 283-299, Ankara-Turkey.

Cevizci, Ahmet (2013). Paradigma Felsefe Sözlüğü. İstanbul: Paradigma.

Çüçen, Kadir (vd.) (2011). Varlkk Felsefesi, Bursa: Ezgi.

Çüçen, Kadir (2012). Martin Heidegger: Varlık ve Zaman, İstanbul: Sentez.

Ergiydiren, Sevinç (2007). Eleştiride Fenomenolojik Yaklaşımlar. İstanbul: Hece.

Dilçin, Cem (1991). Fuzulìnin Bir Gazelinin Şerhi ve Yapısal Yönden İncelenmesi. Türkoloji Dergisi, IX. Cilt, I. Sayı. Ankara: Ankara Üniversitesi Basımevi, s. 43-98.

Haşim, Ahmed (2007). Piyale. (haz. Sabahattin Çağın). İstanbul: Çağrı.

Hartmann, Nicolai (2010). Ontolojinin Işığında Bilgi(Çev. Harun Tepe), Ankara: Türkiye Felsefe Kurumu.

Hegel, Georg Wilhelm F.(1994). Estetik Güzel Sanatlar Üzerine Dersler (Çev. Taylan Altuğ-Hakkı Hünler), İstanbul: Payel.

Heidegger, Martin (2011). Sanat Eserinin Kökeni (çev. Fatih Tepebaşlı), Ankara: De Ki.

Immanuel Kant (2011). Yargı Yetisinin Eleştirisi (çev. Aziz Yardamlı), İstanbul: İdea.

Iser, Wolfgang (1990).Der Akt des Lesen. Theorie astheticher Wirkung. Dritte Auflage, Wilhelm Fink Verlag München.

Tanylddı, Ahmet (2010). İsmâ̂̂l Rusûhî-yi Ankaravî Şerh-i Mesnevî (Mecmû'atu'l-Letâyif ve Matmûratu'l-Ma'ârif) (I. Cilt) (İnceleme-Metin-Sözlük). Erciyes Üniversitesi Sosyal Bilimler Enstitüsü, Basılmamış Doktora Tezi, Kayseri.

Tarancı, Cahit Sıtkı (2005). Otuz Beş Yaş. (der. Asım Bezirci). İstanbul: Can.

Toprak, Metin (2003). Hermeneutik (Yorum Bilgisi) ve Edebiyat. İstanbul: Bulut.

Tunall, İsmail (2011). Sanat Ontolojisi. İstanbul: İnkılâp. 